See discussions, stats, and author profiles for this publication at: https://www.researchgate.net/publication/270106137

\title{
Water quality characteristics and integrated assessment based on multistep correlation analysis in the Danjiangkou Reservoir, China
}

Article in Journal of Environmental Informatics · January 2014

CITATIONS

8

4 authors, including:

Xiang Tan

Chinese Academy of Sciences

21 PUBLICATIONS 447 CITATIONS

SEE PROFILE

Chen Ye

Chinese Academy of Sciences

152 PUBLICATIONS 3,311 CITATIONS

SEE PROFILE

Some of the authors of this publication are also working on these related projects:

heavy metal pollution View project

environmental assessment View project
READS

957

Siyue Li

Chongqing Institute of Green and Intelligent Technology, Chinese Academy of Scienc... 91 PUBLICATIONS 2,071 CITATIONS

SEE PROFILE 


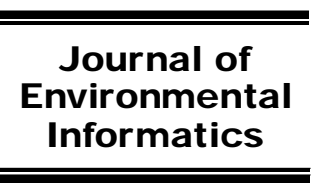

www.iseis.org/jei

\title{
Water Quality Characteristics and Integrated Assessment based on Multistep Correlation Analysis in the Danjiangkou Reservoir, China
}

\author{
X. Tan ${ }^{1,2}$, X. L. Xia ${ }^{2}$, S. Y. Li $^{1}$, and Q. F. Zhang ${ }^{1, *}$ \\ ${ }^{1}$ Key Laboratory of Aquatic Botany and Watershed Ecology, Wuhan Botanical Garden, the Chinese Academy of Sciences, Wuhan 430074, China \\ ${ }^{2}$ Australian Rivers Institute, Griffith University, Nathan QLD4111, Australia
}

Received 10 December 2012; revised 6 August 2014; accepted 15 September 2014; published online 10 March 2015

\begin{abstract}
The Danjiangkou Reservoir is the water source for China's South-to-North Water Transfer Project (Middle Route) which diverts water to the North China Plain for irrigation, industrial and domestic usages. Hence, water quality in the Reservoir is critical for public health and economic development in the reception area. In this study, spatial and temporal patterns of 13 water quality variables including nutrients, heavy metals, and trace elements from China's Environmental Quality Standards for Surface Water (GB3838-2002) were investigated in 8 sites with 2 replicates in four seasons during 2007-2010. Afterwards, multistep correlation analysis based on grey theory was applied to assess water quality. The results indicated that there were dramatic increases in the concentrations of total nitrogen $(\mathrm{TN})$, ammonium nitrogen $\left(\mathrm{NH}_{4}{ }^{+} \mathrm{N}\right)$ and a few heavy metals such as chromium $(\mathrm{Cr})$ and lead $(\mathrm{Pb})$ during the sampling period. The major pollutants in the Reservoir were $\mathrm{TN}, \mathrm{Pb}$, and arsenic (As) with respective average concentrations of $4.6 \mathrm{mg} / \mathrm{L}, 210.4 \mu \mathrm{g} / \mathrm{L}$, and $14.1 \mu \mathrm{g} / \mathrm{L}$, while $\mathrm{Pb}$ and As also reached the maximum contaminant level of USEPA $(15 \mu \mathrm{g} / \mathrm{L}$ and $10 \mu \mathrm{g} / \mathrm{L}$ for $\mathrm{Pb}$ and $\mathrm{As}$, respectively). The $\mathrm{Pb}$ concentration increased 20 times compared to that $(10.6 \mu \mathrm{g} / \mathrm{L})$ in 2004-2006. Water quality in a sampling site varied and could be catego- rized from grade I to V based on the individual variable using the national standard (GB3838-2002). Integrated assessment using all sampled variables simultaneously revealed an overall water quality deterioration from grade I and II in 2007 to grade II and III in 2010 in the Reservoir. The application of multistep correlation analysis based on grey theory demonstrated its feasibility and effectiveness, and could provide a simplified indicator for water quality assessment.
\end{abstract}

Keywords: Grey theory, interbasin water transfer, nutrient, reservoir, seasonal dynamics, spatial pattern, trace elements

\section{Introduction}

Freshwater ecosystems account for only $0.01 \%$ of the world's water resource and occupy about $0.8 \%$ of the Earth's surface, but they provide the essential water needs for humans, support recreation and transportation, and supply electricity and food via such as fishing and farming. Currently $80 \%$ of the world's population is under a high level threat of reduced water security (Vörösmarty et al., 2010), and many lakes, reservoirs, streams and rivers have been facing declining water quality, including increased contamination of heavy metals and trace elements, and nutrient enrichment leading to algal blooms and oxygen sags. This declining water quality has been threatening human water security and biodiversity worldwide, particularly in developing countries (Kelly and Whitton, 1995; Stoermer and Smol, 1999; Hirst et al., 2002; Smith, 2003).

Numerous studies have revealed diverse causes of aquatic ecosystem deterioration, mainly due to the diffused pollu-

* Corresponding author. Tel.: +86 27 87510702; fax: +86 2787510251 .

E-mail address: qzhang@wbgcas.cn (Q. F. Zhang).

ISSN: 1726-2135 print/1684-8799 online

(C) 2015 ISEIS All rights reserved. doi:10.3808/jei.201500296 tion caused by intensive agricultural practices with disproportionate application of fertilizer in addition to industrial pollutants (Carpenter et al., 1998; Zhang et al., 2009; Webster et al., 2012; Chen et al., 2013). Urbanization or intensive land use including grazing and agriculture usually result in nutrient enrichment and increase of other toxicants such as metals, with an increased use of particulate organics such as phosphorus $(\mathrm{P})$ and nitrogen $(\mathrm{N})$ from herbicides or fertilizers, or even toxic chemicals from pesticides (Schmitt, 2004) or from detergents and sewage (Lenat and Crawford, 1994).

The Danjiangkou Reservoir is the water source for China's South-to-North Water Transfer Project (Middle Route), which includes an open channel diverting water to the North China Plain for irrigation, industrial and domestic usages. Therefore, water quality in the Reservoir is crucial for public health and economic development in the reception area. Previous studies have revealed its spatial and temporal variabilities in various water quality variables including nutrients, heavy metals and trace elements for the time period of 2004 2006 ( $\mathrm{Li}$ et al., 2008a, 2009a). Yet there are great demands from the stakeholders and public for a simplified indicator on timely water quality information in the Reservoir for the interbasin water transfer project. In other words, policy makers prefer results or judgments in hierarchic rather than numeric values in practical situations ( $\mathrm{Li}$ et al., 2009b). 
Thus, the objective of this study was to explore the applicability of multistep correlation analysis based on grey theory for water quality assessment in the Reservoir (Deng, 1989). Specifically we intended to: (1) investigate the spatial pattern and temporal dynamics in nutrient, heavy metal, and trace elements during $2007 \sim 2010$ in comparison with those in $2004 \sim 2006$ from Li et al. (2008a, 2009a); (2) compare their overall values with the standards and the contaminant level for potable water in WHO and the US EPA; (3) evaluate the water quality grade using individual variables based on the national standards and an integrated water assessment based on grey theory. Ultimately, this research aimed to formulate water quality monitoring and conservation strategies for the interbasin water transfer project.

\section{Materials and Methods}

\subsection{Study Area}

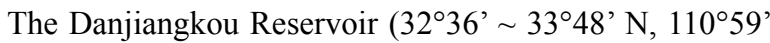
$\sim 111^{\circ} 49^{\prime}$ E) was built in 1970 s with a water surface area of about $450 \mathrm{~km}^{2}$. The dam is $0.8 \mathrm{~km}$ downstream of the junction of the Han River and Dan Rivers in Hubei and Henan provinces, China (Figure 1). The average water surface area would be about $750 \mathrm{~km}^{2}$ with a water storage of 29.05 billionm $^{3}$ by the end of 2014. It is expected that 9.5 billion $\mathrm{m}^{3}$ and 12 billion $\mathrm{m}^{3}$ of water from the Reservoir will be transferred to the reception area in the 2010s and 2030s, respectively. The Danjiangkou Reservoir has a drainage area of $9.5 \times 10^{4} \mathrm{~km}^{2}$.

The reservoir is located in the north subtropical monsoon climatic region. The annual mean temperature is $15 \sim 16^{\circ} \mathrm{C}$. The precipitation amounts to $800 \sim 1000 \mathrm{~mm}$, of which $80 \%$ is in the period from May to October (Li et al., 2009a). Soil types are complex, and they include yellow brown soil, brown soil, yellow cinnamon soil, calcareous soil, and paddy soil (National Soil Survey Office, 1992). Forest vegetation covers approximately $35 \%$ of the catchment, and consists of evergreen forest, coniferous (Pinus massoniana, Cunninghamia lanceolata), deciduous forest, coniferous and broad-leaved mixed forest (Gu et al., 2007; Li et al., 2009b). The area of soil erosion in the Danjiangkou Reservoir watershed and its upper watershed accounts for approximately $41.5 \%$ of total area (Li et al., 2009b). In addition, the local automobile industry contributes much to the pollution loadings of the Reservoir because a city well known for its automobile industry is located on one of the tributary rivers (i.e., Shending River) in a region with poor administrative monitoring effectiveness and little public awareness of the concept of sustainable development.

Eight sampling sites (D1 to D8) were selected in the Reservoir. Four sites (D1 to D4) were located in the Dan Reservoir with a water surface area of $\sim 350 \mathrm{~km}^{2}$. D1 was the appropriate spot to monitor water quality from the Dan River upstream, D2 and D4 were in the middle of the Dan Reservoir, and D3 was the spot where the water transfer project constructed an open channel for water diversion. D5 and D6 were in the middle of the Han Reservoir with a water surface area

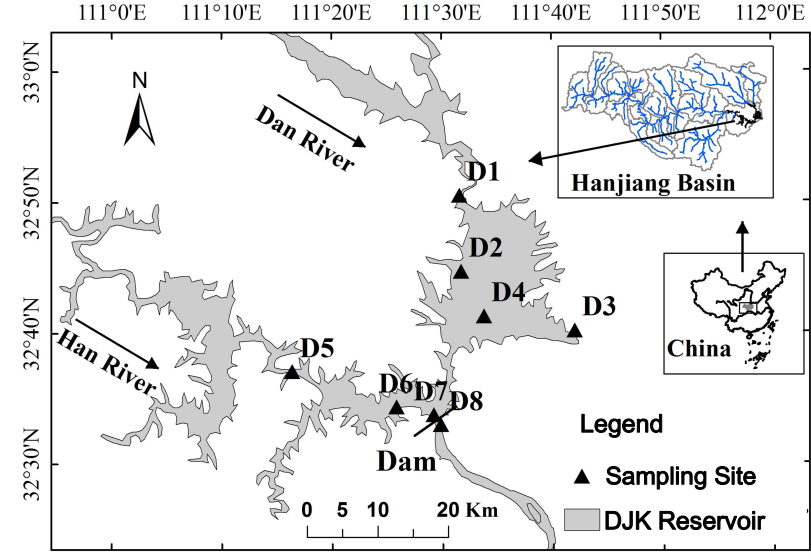

Figure 1. Sampling sites in the Danjiangkou Reservoir, China.

of $401.6 \mathrm{~km}^{2}$ (Li et al., 2008a, 2009a). D7 and D8 were upstream and downstream of the Danjiangkou Dam, suitable for monitoring the water quality due to the longer retention time caused by the dam construction. Water samples were collected in four seasons from 2007 to 2010, specifically, 2007 (January), 2008 (July and November), 2009 (April, August, and November), 2010 (January and April). Based on the hydrological records of the upper Han River basin, the period from July to November was the wet season, and the remainder of the year was the dry season.

\subsection{Water Quality Measurement}

Following WHO Guidelines for drinking-water quality (World Health organization, 2011) and China's Environmental Quality Standards for Surface Water (GB3838-2002), a total of 13 variables were selected and categorized into three groups, i.e., easily purified variables including dissolved oxygen (DO), chemical oxygen demand $\left(\mathrm{COD}_{\mathrm{Mn}}\right)$, and ammoniumnitrogen $\left(\mathrm{NH}_{4}{ }^{+}-\mathrm{N}\right)$; toxic elements, heavy metals or ions including $\mathrm{Cu}, \mathrm{Zn}$, Se, $\mathrm{As}, \mathrm{Cd}, \mathrm{Cr}, \mathrm{Pb}$, and $\mathrm{F}$; other variables including total phosphorus (TP) and total nitrogen (TN) .

A total of 112 water samples (two samples as replicates at each site) were collected in the reservoir. Water samples were all stored at $4{ }^{\circ} \mathrm{C}$ in acid-washed high-density polyethylene (HDPE) bottles. $500 \mathrm{ml}$ of each sample was mixed with $10 \%$ $(\mathrm{v} / \mathrm{v})$ sulphuric acid (final $\mathrm{pH}<2$ ) for analysis of TP, TN and $\mathrm{Mn}$. Water samples of $200 \mathrm{ml}$ were filtered using cellulose nitrate membrane filters (Whatman, aperture $0.45 \mu \mathrm{m}$ ) for ions analysis. $100 \mathrm{ml}$ of this sample was stored for measuring fluorine $(\mathrm{F})$ concentration, while the rest of the samples was acidified with ultra-pure $6 \mathrm{M} \mathrm{HNO}_{3}$ to $\mathrm{pH}<2$ for measurement of copper $(\mathrm{Cu})$, zinc $(\mathrm{Zn})$, selenium $(\mathrm{Se})$, arsenic (As), cadmium $(\mathrm{Cd})$, chromium $(\mathrm{Cr})$ and lead $(\mathrm{Pb})$.

Water temperature $(t), \mathrm{DO}$ and $\mathrm{NH}_{4}{ }^{+}-\mathrm{N}$ were measured in situ using a YSI 6920 multiparameter sonde. The sonde was calibrated using 0 and $100 \%$ oxygen saturation, respectively. Concentrations of trace elements, $\mathrm{Cu}, \mathrm{Zn}, \mathrm{Se}, \mathrm{As}, \mathrm{Cd}, \mathrm{Cr}$, and $\mathrm{Pb}$, were determined using Inductively Coupled Plasma Ato- 
mic Emission Spectrometry (ICP-AES) (IRIS Intrepid II XSP DUO, USA). All the samples for trace elements detection were stored at $-20{ }^{\circ} \mathrm{C}$ until analysis (Demirak et al., 2006). Method accuracy and reproducibility were ensured by using a certified or standard reference material (SPEX CetiPrep Inc, USA). All the samples, certified reference material and blanks were analyzed in batches. Replicates of the certified reference samples showed good accuracy, with recovery rates of trace elements ranging between $90 \%$ (As) and 104\% ( $\mathrm{Zn}$ ). Anions (F) were measured using Dionex Ion Chromatograph (IC) (Dionex Corporation, Sunnyvale, USA). TP was measured by ammonium molybdate spectrophotometric method, TN was determined by the alkaline potassium persulfate digestion-UV spectrophotometric method, and $\mathrm{COD}_{\mathrm{Mn}}$ was determined by the potassium permanganate index method (CSEPB, 2002).

\subsection{Multistep Correlation Analysis based on Grey Theory}

Step 1: Assuming that there are $m$ sites and each site has $n$ assessment indices with different standard values, a sample matrix $X_{m \times n}$ and a standard matrix $S_{l \times n}$ are formed:

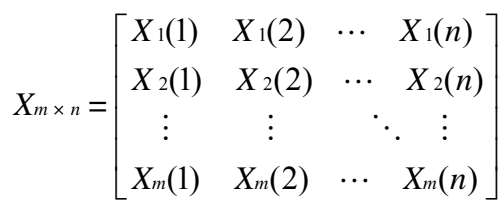

$$
\begin{aligned}
& S_{l \times n}=\left[\begin{array}{cccc}
S_{1}(1) & S_{1}(2) & \cdots & S_{1}(n) \\
S_{2}(1) & S_{2}(2) & \cdots & S_{2}(n) \\
\vdots & \vdots & \ddots & \vdots \\
S_{l}(1) & S_{l}(2) & \cdots & S_{l}(n)
\end{array}\right]
\end{aligned}
$$

where $m$ is the total number of samples; $n$ is the total number of indices in each sample; $l$ is the number of different grades; $a$ and $b$ are the index value of a sample and the standard value of a grade, respectively.

There were 8 sampling sites and 13 indices (i.e., variables here) in this study, and five standards were established for surface water in China (Ministry of Environmental Protection, 2002). Thus, $m=8, n=13, l=5$ in this study. The referred standards are shown in Table 1.

Step 2: Due to the differences in units of indices and the order of magnitude for different index grades, original data were normalized to a value between 0 and 1 before calculating the correlation. Grade I corresponded to 1 and grade V corresponded to 0 . The values of grades II, III, and IV were in the range of 0 to 1 (Buckley, 1985; Xia, 1995).

For the DO, the equations for normalization were the following:

$$
b_{i}(k)=\frac{S_{i}(k)-S_{l}(k)}{S_{1}(k)-S_{l}(k)}
$$

$$
\begin{aligned}
a_{j}(k)= & \left\{\begin{array}{l}
1, X_{j}(k) \geq S_{1}(k) \\
\frac{X_{j}(k)-S_{l}(k)}{S_{1}(k)-S_{l}(k)}, S_{l}(\mathrm{k})<X_{j}(k)<S_{1}(k) \\
0, X_{j}(k) \leq S_{l}(k)
\end{array}\right. \\
& (i=1,2, \ldots, l ; j=1,2, \ldots, m ; k=1,2, \ldots, n)
\end{aligned}
$$

For other indices, the equations were:

$$
\begin{aligned}
& b_{i}(k)=\frac{S_{l}(k)-S_{i}(k)}{S_{l}(k)-S_{1}(k)} \\
& a_{j}(k)=\left\{\begin{array}{l}
1, X_{j}(k) \leq S_{1}(k) \\
\frac{S_{l}(k)-S_{i}(k)}{S_{l}(k)-S_{1}(k)}, S_{l}(\mathrm{k})>X_{j}(k)>S_{1}(k) \\
0, X_{j}(k) \geq S_{l}(k)
\end{array}\right.
\end{aligned}
$$

Consequently the normalized matrices of the standards and the sample matrix were as follows:

$$
\begin{aligned}
A_{m \times n} & =\left[\begin{array}{cccc}
a_{1}(1) & a_{1}(2) & \cdots & a_{1}(n) \\
a_{2}(1) & a_{2}(2) & \cdots & a_{2}(n) \\
\vdots & \vdots & \ddots & \vdots \\
a_{m}(1) & a_{m}(2) & \cdots & a_{m}(n)
\end{array}\right] \\
B_{l \times n} & =\left[\begin{array}{cccc}
b_{1}(1) & b_{1}(2) & \cdots & b_{1}(n) \\
b_{2}(1) & b_{2}(2) & \cdots & b_{2}(n) \\
\vdots & \vdots & \ddots & \vdots \\
b_{l}(1) & b_{l}(2) & \cdots & b_{l}(n)
\end{array}\right]
\end{aligned}
$$

Step 3: the correlation function $\xi_{i j}(k)$ of the sample matrix and the standard matrix (Xia, 1995) is represented by:

$$
\begin{aligned}
\xi_{i j}(k) & =\frac{1-\left|a_{j}(k)-b_{i}(k)\right|}{1+\left|a_{j}(k)-b_{i}(k)\right|} \\
(i & =1,2, \ldots, l ; j=1,2, \ldots, m ; k=1,2, \ldots, n)
\end{aligned}
$$

And the correlation degree $r_{i j}$ is:

$$
\begin{aligned}
r_{i j}= & \sum_{k=1}^{n} w(k) \xi_{i j}(k) \\
& \quad(i=1,2, \ldots, l ; j=1,2, \ldots, m ; k=1,2, \ldots, n)
\end{aligned}
$$

where the $r_{i j}$ value ranges from 0 to $1 . w(k)$ is the weight value of the $k$ th index and is determined by the normalized value for the ratio of $X_{k}$ to $S_{k}$, or i by equal weight (Xia, 1995), $w(k)=$ $1 / \mathrm{n}$ (here $\mathrm{n}=13$ ), $w(k)=0.0769$. Thus the comprehensive assessment association matrix of the sample matrix and the standard matrix is: 

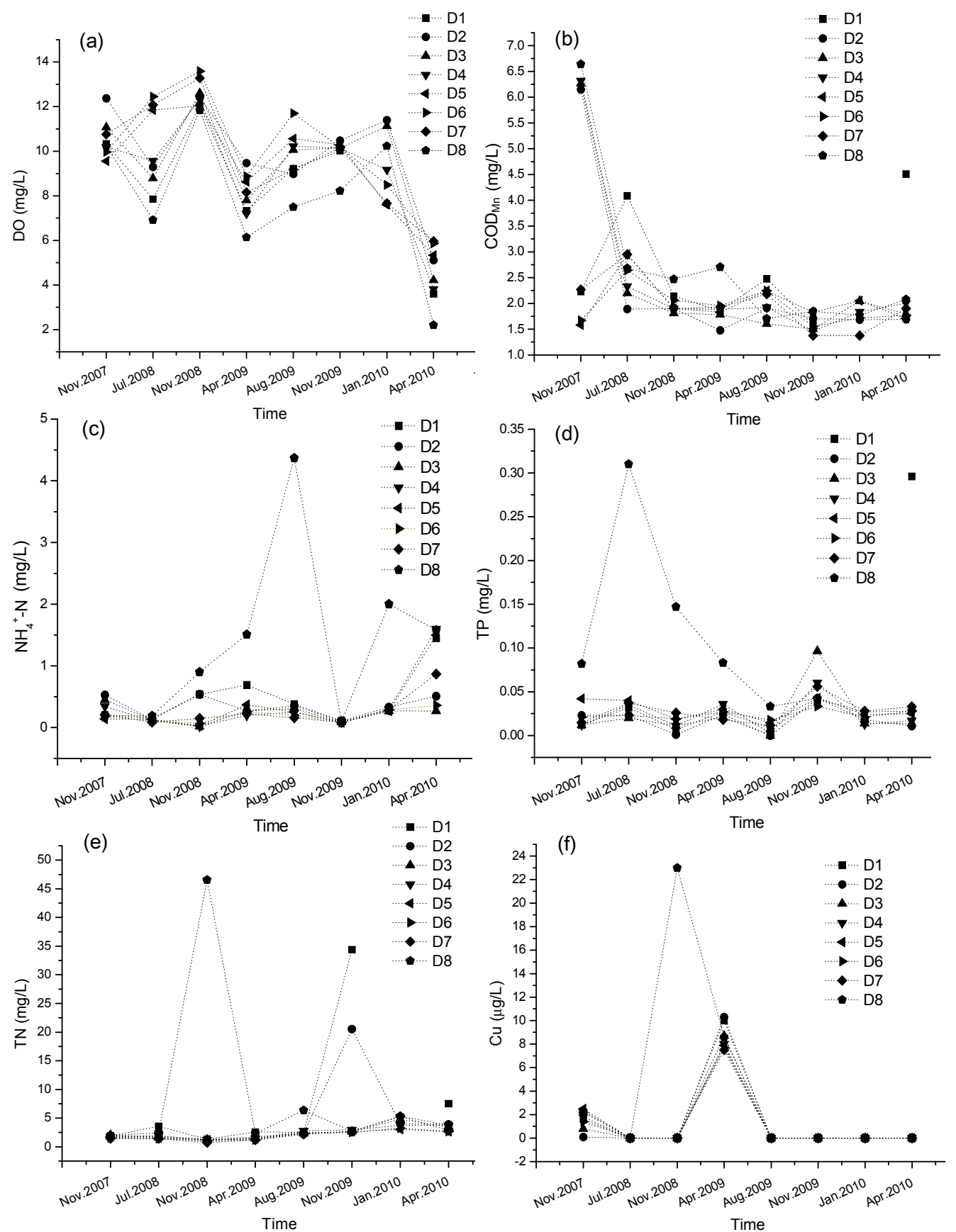

Figure 2 (part 1). Temporal and spatial variations of the water quality in the Danjiangkou Reservoir from 2007 to 2010.

sample 1 sample $2 \cdots$ sample $m$

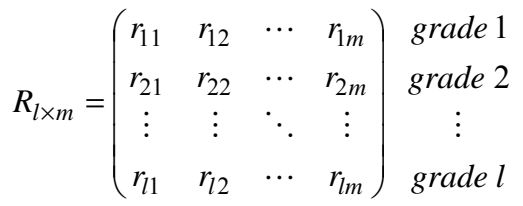

Step 4: Based on the multistep correlation theory, the degree of the sample is classified as the $k$ th degree if the comprehensive value $r_{i k}$ of the ith sample is the greatest.

\subsection{Statistical Analysis}

Analysis of variance (ANOVA) or nonparametric Kruskal-Wallis test (Kruskal and Wallis, 1952) was used to test the significance of the differences in variables among samples from the Dan Reservoir (27 samples with 2 replicates each), Han Reservoir (14 samples with 2 replicates each), upstream (7 samples with 2 replicates each), and downstream of the Dam (7 samples with 2 replicates each). Data initially were tested to determine whether it was normally distributed (Kolmogorov-Smirnov test, $p<0.05$ ) (Frank and Massey, 1951). If 

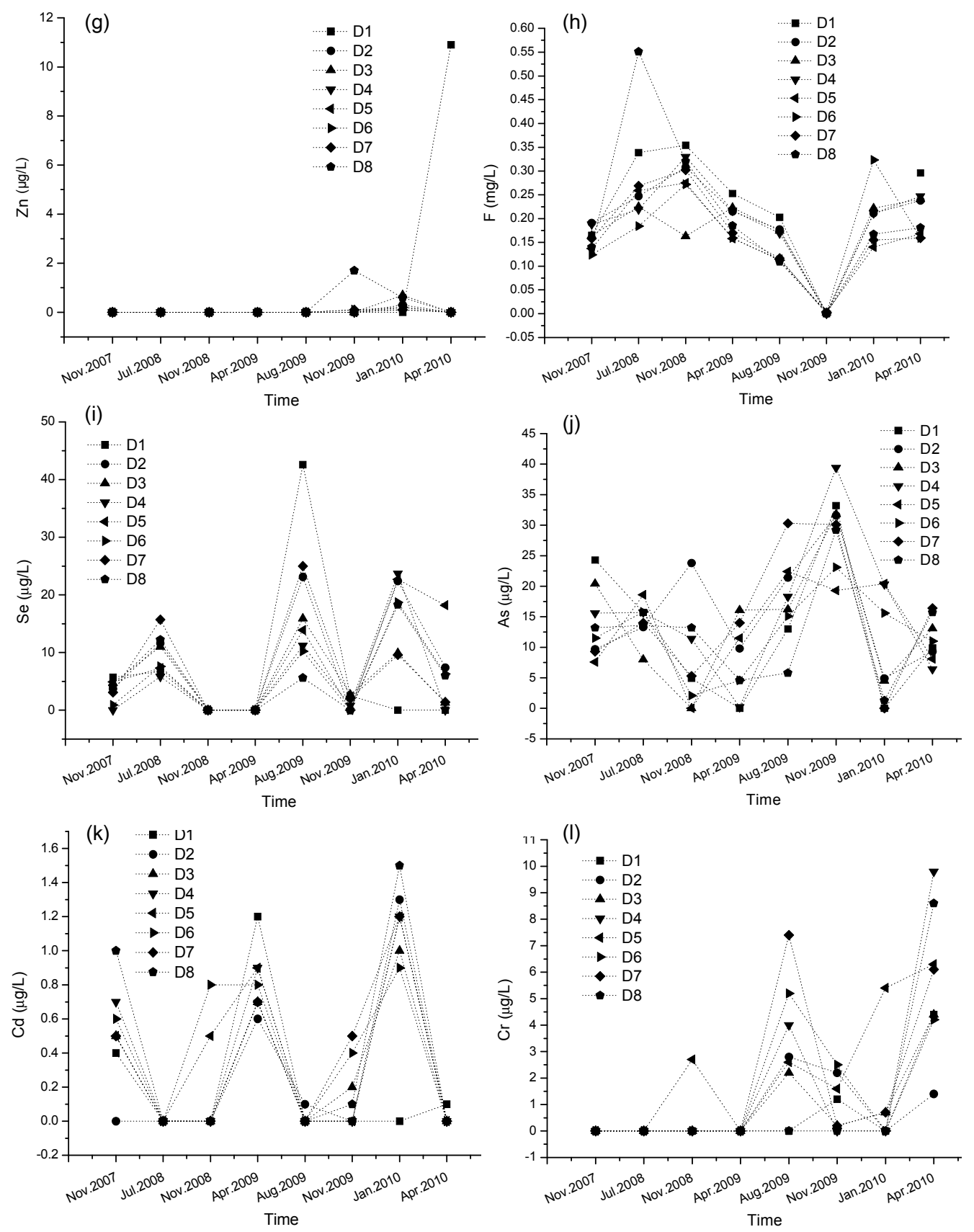

Figure 2 (part 2). Temporal and spatial variations of the water quality in the Danjiangkou Reservoir from 2007 to 2010.

it was not normally distributed, significance of differences was tested using nonparametric Kruskal-Wallis test. Significance of differences was tested using one way analysis of variance (ANOVA) for data originally distributed normally or those after square root transformation. The Least Significant Difference (LSD) test was applied for data with homogeneity of variances using the Levene test (Levene, 1960). Otherwise, the significance was tested using Tamhane's in Post hoc multiple comparisons (Hochberg and Tamhane, 1987). The statistical analysis was conducted using SPSS 16.0. All plotting was completed using Origin Pro 8.

\section{Results}

\subsection{Overall Water Quality Characteristics}

Water quality characteristics of the 13 measured variables were summarized in Table 2 and all variables showed variability during the sampling period. For instance, DO had a wide range of variation from 2.2 to $13.6 \mathrm{mg} / \mathrm{L}$ with an average of $9.5 \mathrm{mg} / \mathrm{L}$. $\mathrm{COD}_{\mathrm{Mn}}$ varied between 1.4 and $6.6 \mathrm{mg} / \mathrm{L}$ with a mean value of $2.3 \mathrm{mg} / \mathrm{L}$. TP was between 0.0 and $0.3 \mathrm{mg} / \mathrm{L}$ with an average of $0.04 \mathrm{mg} / \mathrm{L}$ and $\mathrm{TN}$ ranged from $0.7 \sim 46.6$ $\mathrm{mg} / \mathrm{L}$ with an average of $4.6 \mathrm{mg} / \mathrm{L}$. The variations in the hea- 


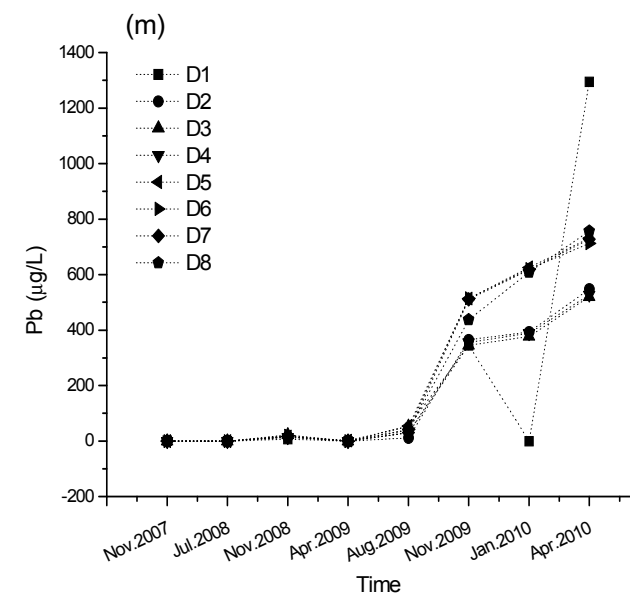

Figure 2 (part 3). Temporal and spatial variations of the water quality in the Danjiangkou Reservoir from 2007 to 2010 .

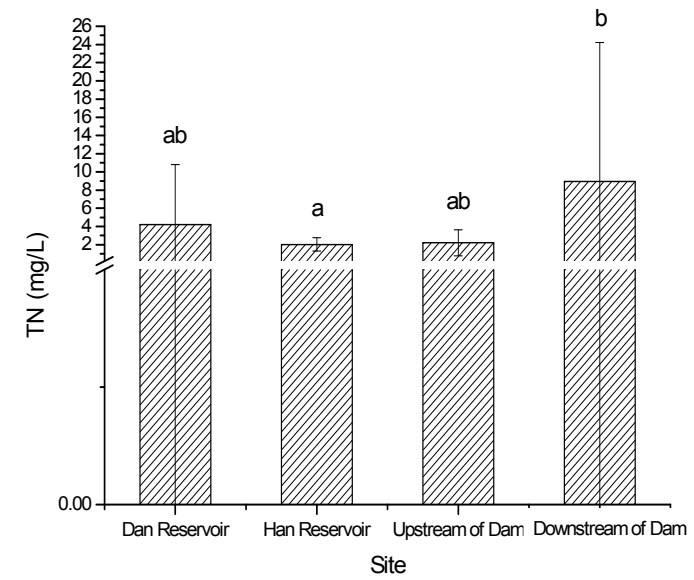

Figure 3. The spatial characteristics of the water quality in the Danjiangkou Reservoir from 2007 to 2010. (Only variable TN with significant difference is indicated here)

vy metals were even greater. All of them ranged from undetectable to a high level, in particular $0 \sim 42.6 \mu \mathrm{g} / \mathrm{L}$ for $\mathrm{Se}$ and $0 \sim 39.4 \mu \mathrm{g} / \mathrm{L}$ for As.

\subsection{Temporal Dynamics and Spatial Pattern of Water Quality}

There was a trend of increasing concentrations of TN, $\mathrm{NH}_{4}{ }^{+}-\mathrm{N}, \mathrm{Cr}$ and $\mathrm{Pb}$ during the sampling period $(2007 \sim 2010)$ (Figure 2). For example, $\mathrm{NH}_{4}{ }^{+}-\mathrm{N}$ increased to about $1.0 \mathrm{mg} / \mathrm{L}$ in 2010 from around $0.5 \mathrm{mg} / \mathrm{L}$ in 2007 . A marked increase in $\mathrm{Pb}$ concentration was observed. In contrast, TP was fairly stable with a concentration of about $0.03 \mathrm{mg} / \mathrm{L}$ with one exception of $0.3 \mathrm{mg} / \mathrm{L}$ downstream of the dam (D8). The concentrations of As fluctuated with an average value of $14.1 \mu \mathrm{g} / \mathrm{L}$ (Table 2; Figure 2). The lowest value, with an average of about $2.0 \mathrm{mg} / \mathrm{L}$, was observed in April 2010.

Seasonality of nutrients and elements was evident in the concentrations of all variables (Table 2). The average TN was $5.8 \mathrm{mg} / \mathrm{L}$ in the wet season, but higher than $2.9 \mathrm{mg} / \mathrm{L}$ in the dry season. In contrast, the average TP in the wet season was similar to that in the dry season, 0.03 and $0.04 \mathrm{mg} / \mathrm{L}$, respectively. The concentrations of most sampled heavy metals and trace elements except As (Its concentration was $17.3 \mu \mathrm{g} / \mathrm{L}$ in the wet season and $10.7 \mu \mathrm{g} / \mathrm{L}$ in the dry season) in the dry season were much higher than those in the wet season. For instance, $\mathrm{Zn}$ concentration in the dry season $(0.4 \mu \mathrm{g} / \mathrm{L})$ was 7 times higher than that in the wet season $(0.06 \mu \mathrm{g} / \mathrm{L})$. Similarly, $\mathrm{Pb}$ concentration $(304.8 \mu \mathrm{g} / \mathrm{L})$ in the dry season was approximately three times as high as that $(119.0 \mu \mathrm{g} / \mathrm{L})$ in the wet season.

There were spatial variabilities in the selected water quality variables (Figures 2, 3). DO showed the highest value upstream of the dam (D6) in November 2008 (13.9 mg/L) and the lowest downstream of the dam (D8) in April 2010 (2.2 $\mathrm{mg} / \mathrm{L}$ ) (Figure 2). On a few occasions, variables with extremely high values were observed for $\mathrm{NH}_{4}{ }^{+}-\mathrm{N}, \mathrm{TP}, \mathrm{TN}, \mathrm{Cu}, \mathrm{Zn}$, and $\mathrm{Pb}$ during the sampling period. For instance, $\mathrm{NH}_{4}^{+}-\mathrm{N}$ concentration was $4.4 \mathrm{mg} / \mathrm{L}$ in August 2009 in site D8 (downstream of the dam), and Zn was $10.9 \mathrm{mg} / \mathrm{L}$ in April 2010 in site D1 (Han Reservoir). The average concentration of $\mathrm{NH}_{4}{ }^{+}-$ $\mathrm{N}$ upstream of the dam (D7) $(1.4 \mathrm{mg} / \mathrm{L})$ was more than four times higher than that downstream of the dam (D8) $(0.3$ $\mathrm{mg} / \mathrm{L})$. Collectively, the concentration of TP was $0.09 \mathrm{mg} / \mathrm{L}$ downstream of the dam, which was 3 times that upstream $(0.03 \mathrm{mg} / \mathrm{L})$. There was a significant difference $(p<0.05)$ in TN between the Han Reservoir and downstream of dam (D8) (Figure 3).

\subsection{Trends of Water Quality and Comparison with Standards of WHO and USEPA}

The average concentrations of $\mathrm{Cu}, \mathrm{Zn}, \mathrm{Cd}$, and $\mathrm{Cr}$ were respectively $13.3,2.0,1.2$, and $6.3 \mu \mathrm{g} / \mathrm{L}$ during the period from 2004 to 2006 (Table 2), and dramatically decreased to one seventh of those $(1.9,0.2,0.3$ and $1.4 \mu \mathrm{g} / \mathrm{L})$ during 2007 $\sim 2010$ in this study. The concentrations of Se also showed a certain decline from 15.4 to $7.8 \mu \mathrm{g} / \mathrm{L}$ between the same time periods. By contrast, the average $\mathrm{Pb}$ concentration of 210.4 $\mu \mathrm{g} / \mathrm{L}$ was 20 times higher than that $(10.6 \mu \mathrm{g} / \mathrm{L})$ in 2004 to 2006 (Table 2). Meanwhile, the average concentrations of $\mathrm{COD}_{\mathrm{Mn}}$ and $\mathrm{NH}_{4}{ }^{+} \mathrm{N}$ increased markedly from 1.92 and 0.16 $\mathrm{mg} / \mathrm{L}$ in the first period to 2.31 and $0.45 \mathrm{mg} / \mathrm{L}$, respectively, in the period 2007 to 2010 .

Measured against the maximum contaminant levels allowed by the US EPA (2006) and WHO (2011), As and Pb were the major trace element pollutants in the Reservoir. Specifically, the concentration of As $(14.1 \mu \mathrm{g} / \mathrm{L})$ was much higher than the maximum contaminant level $(10 \mu \mathrm{g} / \mathrm{L}$, USEPA, 20 12). The $\mathrm{Pb}$ concentrations in 7 sites were more than $210 \mu \mathrm{g} / \mathrm{L}$ after November 2009, which exceeded the maximum contaminant level $(15 \mu \mathrm{g} / \mathrm{L}$, US EPA 2006) by 200 folds (Figure 2).

\subsection{Integrated Water Quality Assessment}

Water quality assessment using individual variables was presented in Figure 4. Assessment at all eight sampling sites 
Table 1. The Standards of WHO Drinking Water and Surface Water in China for the 13 Selected Variables (WHO, 2011; GB3838-2002, Ministry of Environmental Protection, 2002) and their Normalized Values

\begin{tabular}{|c|c|c|c|c|c|c|c|c|c|c|c|c|}
\hline \multirow[b]{2}{*}{ Variable } & \multicolumn{12}{|c|}{ Grade } \\
\hline & $\begin{array}{l}\text { WHO } \\
\text { orig. }\end{array}$ & $\begin{array}{l}\text { MCL } \\
\text { orig. }\end{array}$ & $\begin{array}{l}\text { I } \\
\text { orig. }\end{array}$ & norm. & $\begin{array}{l}\text { II } \\
\text { orig. }\end{array}$ & norm. & $\begin{array}{l}\text { III } \\
\text { orig. }\end{array}$ & norm. & $\begin{array}{l}\text { IV } \\
\text { orig. }\end{array}$ & norm. & $\begin{array}{l}\mathrm{V} \\
\text { orig }\end{array}$ & norm. \\
\hline $\mathrm{DO}(\mathrm{mg} / \mathrm{L})$ & $\mathrm{N} / \mathrm{A}$ & $\mathrm{N} / \mathrm{A}$ & $\geqq 7.5$ & 1.000 & 6 & 0.727 & 5 & 0.545 & 3 & 0.182 & 2 & 0.000 \\
\hline $\mathrm{COD}_{\mathrm{Mn}}(\mathrm{mg} / \mathrm{L})$ & N/A & N/A & $\leqq 2$ & 1.000 & 4 & 0.846 & 6 & 0.692 & 10 & 0.385 & 15 & 0.000 \\
\hline $\mathrm{NH}_{4}{ }^{+}-\mathrm{N}(\mathrm{mg} / \mathrm{L})$ & N/A & N/A & $\leqq 0.15$ & 1.000 & 0.5 & 0.811 & 1 & 0.541 & 1.5 & 0.270 & 2 & 0.000 \\
\hline $\mathrm{TP}(\mathrm{mg} / \mathrm{L})$ & N/A & N/A & $\leqq 0.02$ & 1.000 & 0.1 & 0.789 & 0.2 & 0.526 & 0.3 & 0.263 & 0.4 & 0.000 \\
\hline $\mathrm{TN}(\mathrm{mg} / \mathrm{L})$ & N/A & N/A & $\leqq 0.2$ & 1.000 & 0.5 & 0.811 & 1 & 0.541 & 1.5 & 0.270 & 2 & 0.000 \\
\hline $\mathrm{Cu}(\mu \mathrm{g} / \mathrm{L})$ & 2000 & 1300 & $\leqq 10$ & 1.000 & 1000 & 0.000 & 1000 & 0.000 & 1000 & 0.000 & 1000 & 0.000 \\
\hline $\mathrm{Zn}(\mu \mathrm{g} / \mathrm{L})$ & N/A & N/A & $\leqq 50$ & 1.000 & 1000 & 0.513 & 1000 & 0.513 & 2000 & 0.000 & 2000 & 0.000 \\
\hline $\mathrm{F}(\mathrm{mg} / \mathrm{L})$ & 1.5 & 4.0 & $\leqq 1$ & 1.000 & 1 & 1.000 & 1 & 1.000 & 1.5 & 0.000 & 1.5 & 0.000 \\
\hline $\mathrm{Se}(\mu \mathrm{g} / \mathrm{L})$ & 40 & 50 & $\leqq 10$ & 1.000 & 10 & 1.000 & 10 & 1.000 & 20 & 0.000 & 20 & 0.000 \\
\hline As $(\mu \mathrm{g} / \mathrm{L})$ & 10 & 10 & $\leqq 50$ & 1.000 & 50 & 1.000 & 50 & 1.000 & 100 & 0.000 & 100 & 0.000 \\
\hline $\mathrm{Cd}(\mu \mathrm{g} / \mathrm{L})$ & 3 & 5 & $\leqq 1$ & 1.000 & 5 & 0.556 & 5 & 0.556 & 5 & 0.556 & 10 & 0.000 \\
\hline $\mathrm{Cr}(\mu \mathrm{g} / \mathrm{L})$ & 50 & 100 & $\leqq 10$ & 1.000 & 50 & 0.556 & 50 & 0.556 & 50 & 0.556 & 100 & 0.000 \\
\hline $\mathrm{Pb}(\mu \mathrm{g} / \mathrm{L})$ & 10 & 15 & $\leqq 10$ & 1.000 & 10 & 1.000 & 50 & 0.556 & 50 & 0.556 & 100 & 0.000 \\
\hline
\end{tabular}

* Grade I, headwaters and water in nature reserves; Grade II, water resource area for collecting water for domestic potable supply systems, habitat for endangered species, spawning ground of fish and shrimp, feeding ground of juvenile fish; Grade III, water resource area for collecting water for domestic potable supply systems, fishery water area including wintering ground for fish and shrimp, corridor of breeding migration and swimming area; Grade IV, industrial water and recreational waternon contact with humans (e.g. boating, tourism); Grade V, agricultural water and water for recreational environment use (e.g. tourism). MCL, maximum contaminant level (US EPA, 2006); orig.: orgina; norm.: normalized.

Table 2. Characteristics of Water Quality in the Danjiangkou Reservoir, China (2004-2006; 2007-2010)

\begin{tabular}{|c|c|c|c|c|c|c|c|c|}
\hline \multirow[t]{2}{*}{ Variable (Unit) } & \multicolumn{2}{|c|}{$\begin{array}{l}\text { Overall } \\
(2004-2006)^{*}\end{array}$} & \multicolumn{2}{|l|}{$\begin{array}{l}\text { Overall } \\
(2007-2010)\end{array}$} & \multicolumn{2}{|c|}{$\begin{array}{l}\text { Wet season } \\
\text { (Jul.-Nov.) }(2007-2010)\end{array}$} & \multicolumn{2}{|c|}{$\begin{array}{l}\text { Dry season } \\
\text { (Dec.-Jun.) (2007-2010) }\end{array}$} \\
\hline & Mean \pm SD & Range & Mean \pm SD & Range & Mean \pm SD & Range & Mean \pm SD & Range \\
\hline $\mathrm{t}\left({ }^{\circ} \mathrm{C}\right)$ & 19.0 & $19.0-30.6$ & $17.5 \pm 6.8$ & $8.5-30.0$ & $17.8 \pm 6.0$ & $11.3-28.5$ & $17.3 \pm 7.6$ & $8.5-30.0$ \\
\hline $\mathrm{DO}^{*}\left(\mathrm{mg} \mathrm{L}^{-1}\right)$ & 10.3 & $6.4-15.2$ & $9.5 \pm 2.6$ & $2.2-13.6$ & $10.7 \pm 1.4$ & $7.5-13.6$ & $7.9 \pm 3.0$ & $2.2-12.5$ \\
\hline $\mathrm{COD}_{\mathrm{Mn}}\left(\mathrm{mg} \mathrm{L}^{-1}\right)$ & 1.9 & $0.8-2.7$ & $2.3 \pm 1.2$ & $1.4-6.6$ & $2.5 \pm 1.5$ & $1.4-6.6$ & $2.2 \pm 0.7$ & $1.4-4.5$ \\
\hline $\mathrm{NH}_{4}^{+}-\mathrm{N}\left(\mathrm{mg} \mathrm{L}^{-1}\right)$ & 0.2 & $0.07-0.7$ & $0.5 \pm 0.7$ & $0.02-4.4$ & $0.4 \pm 0.8$ & $0.02-4.4$ & $0.5 \pm 0.5$ & $0.09-2.0$ \\
\hline $\mathrm{TP}\left(\mathrm{mg} \mathrm{L}^{-1}\right)$ & N/A & N/A & $0.04 \pm 0.05$ & ND -0.31 & $0.03 \pm 0.03$ & ND -0.15 & $0.04 \pm 0.07$ & $0.01-0.3$ \\
\hline $\mathrm{TN}\left(\mathrm{mg} \mathrm{L}^{-1}\right)$ & $\mathrm{N} / \mathrm{A}$ & N/A & $4.6 \pm 7.7$ & $0.7-46.6$ & $5.8 \pm 11.5$ & $0.7-46.6$ & $2.9 \pm 1.5$ & $1.2-7.5$ \\
\hline $\mathrm{Cu}\left(\mu \mathrm{g} \mathrm{L}^{-1}\right)$ & $13.3 \pm 21.6$ & ND - 56.3 & $1.9 \pm 4.2$ & ND -23.0 & $1.1 \pm 4.1$ & ND -23.0 & $2.9 \pm 4.2$ & ND -10.3 \\
\hline $\mathrm{Zn}\left(\mu \mathrm{g} \mathrm{L}^{-1}\right)$ & $2.0 \pm 7.1$ & ND - 44.0 & $0.2 \pm 1.4$ & ND -10.9 & $0.06 \pm 0.3$ & ND -1.7 & $0.4 \pm 2.0$ & $0.00-10.9$ \\
\hline $\mathrm{F}\left(\mathrm{mg} \mathrm{L}^{-1}\right)$ & N/A & N/A & $0.2 \pm 0.10$ & ND -0.6 & $0.2 \pm 0.1$ & ND -0.4 & $0.2 \pm 0.08$ & $0.1-0.6$ \\
\hline $\operatorname{Se}\left(\mu \mathrm{g} \mathrm{L}^{-1}\right)$ & $15.4 \pm 18.8$ & ND - 50.2 & $7.8 \pm 8.9$ & ND -42.6 & $7.6 \pm 10.3$ & ND -42.6 & $7.9 \pm 7.8$ & ND -23.7 \\
\hline As $\left(\mu \mathrm{g} \mathrm{L}^{-1}\right)$ & $11.1 \pm 20.8$ & ND - 120.7 & $14.1 \pm 9.1$ & ND -39.4 & $17.3 \pm 10.5$ & ND -39.4 & $10.7 \pm 6.0$ & ND -20.4 \\
\hline $\mathrm{Cd}\left(\mu \mathrm{g} \mathrm{L}^{-1}\right)$ & $1.2 \pm 1.9$ & ND - 6.0 & $0.3 \pm 0.44$ & ND -1.5 & $0.2 \pm 0.3$ & ND -1.0 & $0.5 \pm 0.5$ & ND -1.5 \\
\hline $\mathrm{Cr}\left(\mu \mathrm{g} \mathrm{L}^{-1}\right)$ & $6.3 \pm 8.2$ & ND - 27.2 & $1.4 \pm 2.4$ & ND -9.8 & $1.1 \pm 1.8$ & ND -7.4 & $1.7 \pm 2.9$ & ND -9.8 \\
\hline $\mathrm{Pb}\left(\mu \mathrm{g} \mathrm{L}^{-1}\right)$ & $10.6 \pm 16.7$ & ND -48.0 & $210.4 \pm 293.6$ & ND - 1294.6 & $119.0 \pm 183.2$ & ND -514.70 & $304.8 \pm 354.0$ & ND -1294.6 \\
\hline
\end{tabular}

* see Li et al., 2008a, 2009 for details. N/A means not available. ND means values below the detection limits.

using China's Environmental Quality Standards in Surface Water for $\mathrm{Cu}, \mathrm{Zn}, \mathrm{F}, \mathrm{As}, \mathrm{Cd}$ and $\mathrm{Cr}$ indicated that water quality was assessed as grade I, and there was no significant change in water quality during the sampling period (results not presented). On the other hand, water quality varied even at the same time and same site depending on the individual variables (DO, $\mathrm{COD}_{\mathrm{Mn}}, \mathrm{NH}_{4}{ }^{+}-\mathrm{N}, \mathrm{TP}, \mathrm{TN}, \mathrm{Se}$ and $\mathrm{Pb}$ ) being assessed. For example, water quality was categorized as grade 1 by Se, grade II by $\mathrm{COD}_{\mathrm{Mn}}$, grade III by $\mathrm{DO}, \mathrm{NH}_{4}-\mathrm{N}$ and $\mathrm{TP}$, grade $\mathrm{V}$ by $\mathrm{TN}$ and $\mathrm{Pb}$ for site $\mathrm{D} 1$ in the sampling time of April 2010. Even though there was variation among sampling sites, water quality was generally degraded from 2007 to 2010 in particular, considering that waters were classed as grade III or IV in 2007, and grade V in 2010 by the assessment for a single variable (TN), and as grade I in 2007 but grade $\mathrm{V}$ in 2010 by the assessment for $\mathrm{Pb}$ concentration.

The correlation of all 13 water quality variables with normalized grade criteria (Table 1) was shown in Table 3. Integrated evaluation based on multistep correlation analysis using all 13 variables simultaneously demonstrated that water quality was classified as either grade I or II in 2007 for most of the sampling sites and times, but gradually deteriorated to grade II or III in 2010 (Table 3). Sampling site D1 was even categorized as grade IV with the strongest correlation with grade IV of 0.726 . Spatial variability in water quality was also evident among the eight sampling sites. 
Table 3. The Correlation Degree and Results Evaluated by the Multistep Correlation Analysis from 2007 to 2010

\begin{tabular}{|c|c|c|c|c|c|c|c|c|c|c|c|c|c|}
\hline & $\mathrm{I}$ & II & III & IV & $\mathrm{V}$ & $\mathrm{ING}$ & & $\mathrm{I}$ & II & III & IV & $\mathrm{V}$ & ING \\
\hline $2007-11$ & & & & & & & $2008-7$ & & & & & & \\
\hline D1 & 0.835 & 0.795 & 0.620 & 0.400 & 0.180 & I & D1 & 0.821 & 0.794 & 0.629 & 0.414 & 0.197 & I \\
\hline D2 & 0.767 & 0.801 & 0.696 & 0.509 & 0.286 & II & D2 & 0.786 & 0.798 & 0.678 & 0.484 & 0.257 & II \\
\hline D3 & 0.762 & 0.789 & 0.68 & 0.495 & 0.281 & II & D3 & 0.807 & 0.821 & 0.697 & 0.490 & 0.247 & II \\
\hline D4 & 0.795 & 0.819 & 0.703 & 0.502 & 0.263 & II & D4 & 0.837 & 0.795 & 0.619 & 0.397 & 0.177 & I \\
\hline D5 & 0.854 & 0.815 & 0.638 & 0.408 & 0.172 & I & D5 & 0.874 & 0.846 & 0.668 & 0.423 & 0.168 & I \\
\hline D6 & 0.871 & 0.831 & 0.648 & 0.407 & 0.159 & I & D6 & 0.888 & 0.851 & 0.664 & 0.410 & 0.149 & I \\
\hline D7 & 0.882 & 0.849 & 0.666 & 0.415 & 0.156 & I & D7 & 0.803 & 0.835 & 0.724 & 0.518 & 0.267 & II \\
\hline D8 & 0.763 & 0.789 & 0.68 & 0.496 & 0.281 & II & D8 & 0.674 & 0.748 & 0.705 & 0.576 & 0.385 & II \\
\hline 2008-11 & & & & & & & $2009-4$ & & & & & & \\
\hline D1 & 0.891 & 0.870 & 0.689 & 0.429 & 0.158 & I & D1 & 0.798 & 0.793 & 0.650 & 0.446 & 0.229 & I \\
\hline D2 & 0.872 & 0.888 & 0.734 & 0.479 & 0.201 & II & D2 & 0.852 & 0.821 & 0.648 & 0.418 & 0.180 & I \\
\hline D3 & 0.887 & 0.878 & 0.705 & 0.445 & 0.169 & I & D3 & 0.879 & 0.848 & 0.668 & 0.420 & 0.161 & I \\
\hline D4 & 0.902 & 0.886 & 0.702 & 0.433 & 0.153 & I & D4 & 0.880 & 0.848 & 0.666 & 0.418 & 0.159 & I \\
\hline D5 & 0.899 & 0.885 & 0.704 & 0.435 & 0.156 & I & D5 & 0.881 & 0.862 & 0.687 & 0.435 & 0.170 & I \\
\hline D6 & 0.910 & 0.895 & 0.709 & 0.432 & 0.147 & I & D6 & 0.909 & 0.877 & 0.683 & 0.413 & 0.137 & I \\
\hline D7 & 0.942 & 0.915 & 0.703 & 0.406 & 0.114 & I & D7 & 0.910 & 0.872 & 0.675 & 0.405 & 0.131 & I \\
\hline D8 & 0.760 & 0.826 & 0.738 & 0.547 & 0.314 & II & D8 & 0.721 & 0.757 & 0.671 & 0.516 & 0.322 & II \\
\hline $2009-8$ & & & & & & & 2009-11 & & & & & & \\
\hline D1 & 0.767 & 0.801 & 0.690 & 0.500 & 0.283 & II & D1 & 0.606 & 0.648 & 0.605 & 0.522 & 0.398 & II \\
\hline D2 & 0.788 & 0.802 & 0.670 & 0.470 & 0.253 & II & D2 & 0.605 & 0.649 & 0.606 & 0.523 & 0.399 & II \\
\hline D3 & 0.768 & 0.816 & 0.728 & 0.544 & 0.304 & II & D3 & 0.599 & 0.653 & 0.619 & 0.539 & 0.413 & II \\
\hline D4 & 0.876 & 0.898 & 0.746 & 0.485 & 0.200 & II & D4 & 0.604 & 0.651 & 0.611 & 0.528 & 0.403 & II \\
\hline D5 & 0.781 & 0.823 & 0.727 & 0.535 & 0.290 & II & D5 & 0.605 & 0.649 & 0.606 & 0.523 & 0.399 & II \\
\hline D6 & 0.870 & 0.893 & 0.746 & 0.490 & 0.206 & II & D6 & 0.606 & 0.647 & 0.604 & 0.521 & 0.397 & II \\
\hline D7 & 0.774 & 0.786 & 0.663 & 0.472 & 0.260 & II & D7 & 0.604 & 0.651 & 0.610 & 0.527 & 0.402 & II \\
\hline D8 & 0.814 & 0.818 & 0.666 & 0.448 & 0.216 & II & D8 & 0.605 & 0.649 & 0.606 & 0.523 & 0.399 & II \\
\hline \multirow[t]{2}{*}{ 2010-1 } & & & & & & & $2010-4$ & & & & & & \\
\hline & & & & & & & D1 & 0.461 & 0.628 & 0.725 & 0.726 & 0.608 & IV \\
\hline D2 & 0.475 & 0.576 & 0.615 & 0.610 & 0.535 & III & D2 & 0.635 & 0.715 & 0.683 & 0.574 & 0.409 & II \\
\hline D3 & 0.626 & 0.665 & 0.610 & 0.515 & 0.381 & II & D3 & 0.628 & 0.694 & 0.659 & 0.559 & 0.405 & II \\
\hline D4 & 0.475 & 0.575 & 0.613 & 0.607 & 0.533 & III & D4 & 0.501 & 0.606 & 0.643 & 0.622 & 0.522 & III \\
\hline D5 & 0.476 & 0.575 & 0.611 & 0.606 & 0.532 & III & D5 & 0.476 & 0.613 & 0.678 & 0.668 & 0.565 & III \\
\hline D6 & 0.522 & 0.628 & 0.658 & 0.624 & 0.511 & III & D6 & 0.670 & 0.726 & 0.662 & 0.534 & 0.367 & II \\
\hline D7 & 0.626 & 0.666 & 0.613 & 0.518 & 0.383 & II & D7 & 0.640 & 0.721 & 0.687 & 0.574 & 0.408 & II \\
\hline D8 & 0.434 & 0.572 & 0.654 & 0.674 & 0.597 & IIII & D8 & 0.485 & 0.594 & 0.641 & 0.633 & 0.541 & III \\
\hline
\end{tabular}

*See Table 1 for grade descriptors. ING: Integrated grade.

\section{Discussion}

\subsection{The Spatial Pattern of Water Quality}

The Danjiangkou Reservoir has a large water surface area of about $450 \mathrm{~km}^{2}$. Understandably, there was spatial variation in water quality variables and difference in assessed grades in such a large water body (Figure 2; Table 3). Also, the reservoir is located on the junction of the Han River and Dan River, whose basins have dramatically different socioeconomic and environmental characteristics (e.g., topography, land use, etc.) (Figure 1; Li et al., 2008b). However, these different characteristics do not account for the significant differences in water quality variables between the Han and Dan reservoirs as previously assumed (Figure 3), even though their phytoplankton composition was quite different (Tan et al., 2011).
Differences between the reservoir and the downstream site groups in TN were evident. The average concentration of TN downstream of the dam was several times higher than that in the Han Reservoir and the difference between two groups was significant $(p<0.05)$. A similar result has also been observed downstream of the nearby Three Gorges Dam (Müller et al., 2008). This result is probably due to the long water retention time for nutrients in the reservoir (Cogels et al., 1997; Soares et al., 2008). A change of hydraulic regime may cause alteration of nutrient availability and further change of the structure of the aquatic ecosystem in the Reservoir, for example the conversion from lotic benthos to lentic organisms (Baxter, 1977; Stevenson et al., 1996; Cogels et al., 1997; Wei et al., 2009;). The natural hydraulic regime has been altered by the dam construction and impoundments, consequently, some features of lakes, e.g. thermal stratification and oxygen 

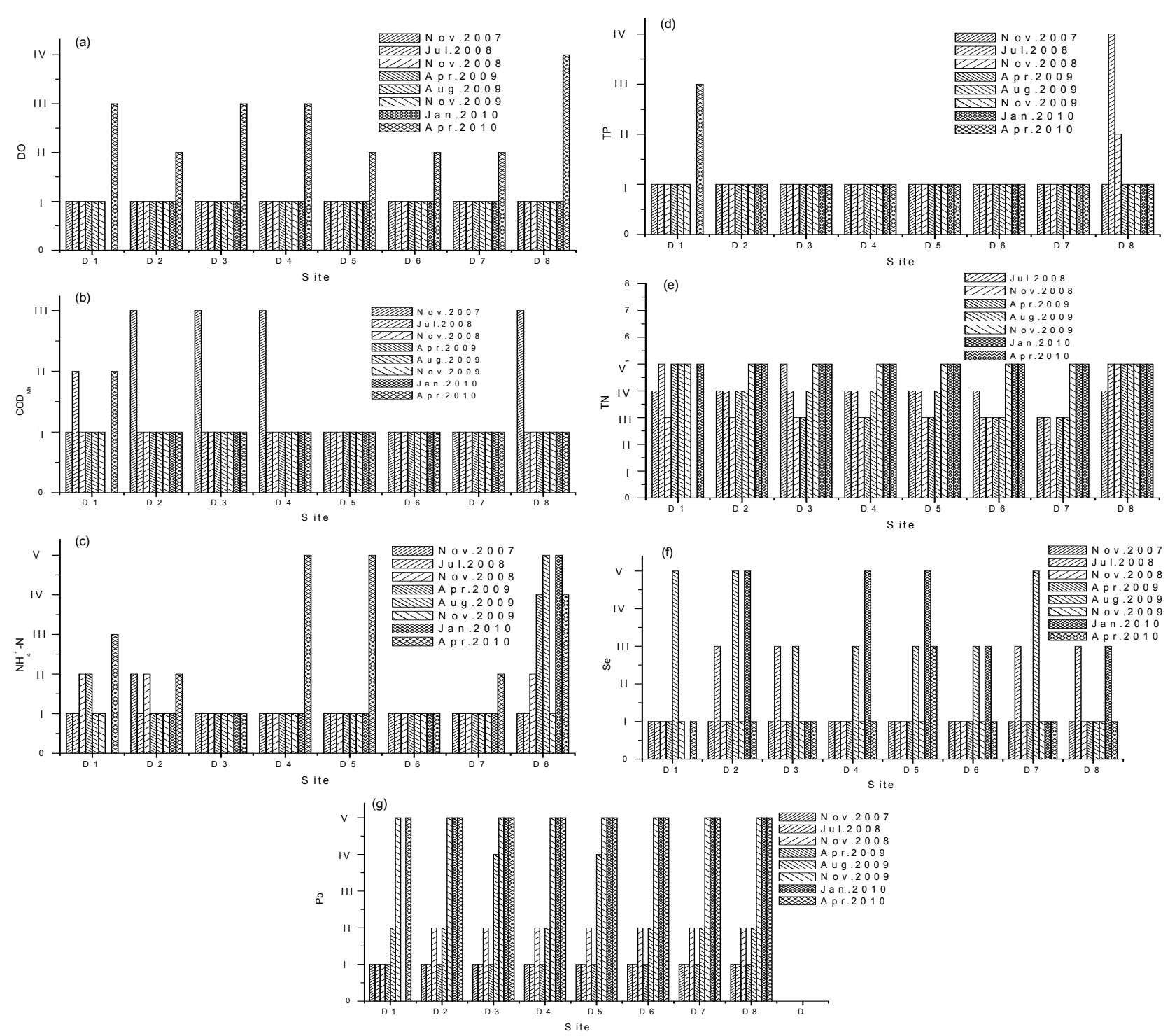

Figure 4. Water quality assessment using individual variable by the China's Environmental Quality Standards in Surface Water (GB3838-2002).

depletion that rarely occur in rivers, can develop in the reservoir (Baxter, 1977). As a result, predictions of excessive growth of phytoplankton/algae bloom should be of great concern in the Danjiangkou Reservoir especially immediately behind the dam.

\subsection{The Toxicity of Excessive Trace Elements and Trends of the Water Quality}

The decreases of concentration of $\mathrm{Cu}, \mathrm{Zn}, \mathrm{Cd}, \mathrm{Cr}$ and $\mathrm{Se}$ imply that conservation efforts including control of industry and mining wastes upstream of the Reservoir may have been effective. By contrast, the exceptional increase of $\mathrm{Pb}$ concentration may be caused by improvement of transportation network and consequent increase in vehicle exhaust pollutants in the upper Han River basin or by mining and mining-related activities (Garelick et al., 2008; Søndergaard et al., 2010). Arsenic-containing bedrock formations are well known in some regions of China (Garelick et al., 2008), and natural weathering and atmospheric deposition might have introduced As to the waters. Therefore, regulation on mining activities and ecological restoration on abandoned mining fields should be considered and implemented to prevent $\mathrm{As}$ and $\mathrm{Pb}$ leaching into surface water in the upper Han River basin.

The high average concentrations of $\mathrm{COD}_{\mathrm{Mn}}$ and $\mathrm{NH}_{4}{ }^{+}-\mathrm{N}$ in the period of 2007 to 2010 were slightly higher than those in 2006, implying more intensive agricultural activities upstream of the Reservoir. In China, nitrogen fertilizer application has increased substantially since the 1980's (Zhu and Chen, 2002), and may have largely contributed to high nitrogen levels in waters of agricultural areas (Lockeretz et al., 1981). In the drainage basin of the Danjiangkou Reservoir, a large proportion of the 13 million residents live by intensive agriculture along the rivers (Zhang et al., 2009). Higher levels of $\mathrm{TN}$ concentration $(5.8 \mathrm{mg} / \mathrm{L})$ in the Reservoir in the wet 
season than in the dry season can be a result of runoff and leaching from the agricultural soils. As a result of nitrogen leaching from agriculture, algal blooms in freshwater ecosystems have occurred more frequently due to the increase of bioavailable dissolved inorganic forms of nitrogen (Carpenter et al., 1998; Zhu and Chen, 2002; Webster et al., 2012). The nitrogen pollution indicated by $\mathrm{TN}$ and $\mathrm{NH}_{4}{ }^{+}-\mathrm{N}$ has worsened in the Danjiangkou Reservoir since 2004 (Table 2; Figure 4), presumably through agricultural activities in its upper streams. Additionally, the expansion of the Reservoir for the interbasin water transfer project could increase the hydraulic retention time which is the most influential factor affecting the algal growth (Kawara et al., 1998). Nitrogen reduction into river system of the upper streams through various ecological restoration programmes (e.g., Green-for-Grain, Slope Land Restoration) is critical for water conservation in the Reservoir.

\subsection{Integrated Water Quality Assessment}

Water quality could be graded based on the assessment using individual water quality variables (Figure 4). For instance, water was characterized as grade I for TP but at the same time as grade $\mathrm{V}$ using $\mathrm{TN}$ and $\mathrm{Pb}$ (Figure 4). In the integrated assessment concerning multivariables, correlation function $\xi_{i j}(k)$ indicates the similarity of sample matrix to different standards, and hence provides a simplified and overall water quality assessment showing that water quality in the Reservoir has deteriorated from grade I and II in 2007 to grade II and III in 2010 (Deng, 1989). Even though water in grade III still meets the criteria for drinking water according to WHO and China's national standards (Table 1), the trend of water deterioration in recent years should be of great concern for the interbasin South-to-North Water Transfer Project (Li et al., 2008a, 2008b; Zhang, 2009; Zhang et al., 2009).

Presumably, the sources for each of the pollutants were different, and nutrient enrichment primarily through agricultural runoffs does not necessarily cause increases in heavy metals and trace elements, which result primarily from mining and transportation (Li et al., 2008b, 2009a). However, individual variable assessment does have its advantage by indicating the primary pollutants in waters, which could be essential for prioritizing conservation efforts for a given region.

Grey system theory has been applied in water quality assessment, eco-environmental vulnerability evaluation and even services evaluation (Xia, 1995; Mikhailov and Tsvetinov, 2004; Li et al., 2009b). Multistep correlation analysis is part of grey system theory, and it is capable of deriving complicated interrelationships among multiple factors and tacking uncertainty and imprecision (Mikhailov and Tsvetinov, 2004; Morán et al., 2006). Its application in water quality assessment could provide systematic and comprehensive assessment of water quality. In this study, assessment using individual variables of $\mathrm{TN}$ and $\mathrm{Pb}$ indicated water quality of grade IV and $\mathrm{V}$ on a few occasions (Figure 4). Integrated assessment based on multistep correlation analysis using all 13 water quality variables includes much more information, and provides an integrated indicator or standard for water quality.

\section{Conclusions}

There were great temporal dynamics in water quality in the extensive Danjiangkou Reservoir from 2007 to 2010. The major pollutants in the Reservoir were nitrogen $(\mathrm{N})$, lead $(\mathrm{Pb})$, and arsenic (As). The concentration of As exceeded the maximum allowable contaminant level of USEPA and $\mathrm{Pb}$ was 20 times higher than the standards of WHO. The mean TN concentration was twice as much as that in the dry season. On occasions, water quality based on $\mathrm{TN}$ and $\mathrm{Pb}$ was categorized as grade $\mathrm{V}$ according to the China's Environmental Quality Standards for Surface Water. The integrated evaluation demonstrates that the overall water quality in the Reservoir declined from grade I and II in 2007 to grade II and III in 2010 in the Reservoir. Greater efforts must be made to reduce nitrogen, $\mathrm{As}$ and $\mathrm{Pb}$ pollution for water conservation in the Reservoir.

Acknowledgments. The research was funded by the National Natural Science Foundation of China (Nos. 31200354, 31130010, 31100347) and the National Key Technology R \& D Program (2012BAC06C03). We gratefully acknowledge Dr. Yongyong Zhang for his contribution in the multistep correlation analysis and Mr. Duncan Frewin for editing the manuscript.

\section{References}

Baxter, R.M. (1977). Environmental effects of dams and impoundments. Annu. Rev. Ecol. Syst., 8, 255-283. http://dx.doi.org/10.11 46/ annurev.es.08.110177.001351

Buckley, J.J. (1985). Fuzzy hierarchical analysis. Fuzzy Sets Syst., 17(3), 233-247. http://dx.doi.org/10.1016/0165-0114(85)9009 0-9

Carpenter, S.R., Caraco, N.F., Correll, D.L., Howarth, R.W., Sharpley, A.N., and Smith, V.H. (1998). Nonpoint pollution of surface waters with phosphorus and nitrogen. Ecol. Appl., 8(3), 559-568. http://dx.doi.org/10.1890/1051-0761(1998)008[0559:NPOSWW] 2.0.CO;2

Chen, Y., Cheng, S., Liu, L., Guo, X., Wang, Z., Qin, C., Hao, R., Lu, J., and Gao, J. (2013). Assessing the effects of land use changes on non-point source pollution reduction for the Three Gorges watershed using the SWAT model. J. Environ. Inf., 22(1), 13-26. http:// dx.doi.org/10.3808/jei.201300242

CSEPB (Chinese State Environment Protection Bureau) (2002). Water and Wastewater Monitoring Analysis Methods (4th edition), Chinese Environment Science Press, Beijing, China.

Cogels, F., Coly, A., and Niang, A. (1997). Impact of dam construction on the hydrological regime and quality of a Sahelian Lake in the River Senegal basin. Regul. Rivers: Res. Manage., 13(1), 27-41. http://dx.doi.org/10.1002/(SICI)1099-1646(199701)13:1<27::AID -RRR421>3.0.CO;2-G

Deng, J. (1989). Introduction to Grey System Theory. The Journal of Grey Systems: 1, Sci-tech Information Services, England and China Petroleum Industry Press, China.

Demirak, A., Yilmaz, F., Tuna, A.L., and Ozdemir, N. (2006). Heavy metals in water, sediment and tissues of Leuciscus cephalus from a stream in southwestern Turkey. Chemosphere, 63(9), 1451-1458. http://dx.doi.org/10.1016/j.chemosphere.20 05.09.033

Frank, J., and Massey, J. (1951). The Kolmogorov-Smirnov test for goodness of fit. J. Am. Stat. Assoc., 46 (253), 68-78. http:// dx.doi. org/10.1080/01621459.1951.10500769

Garelick, H., Jones, H., Dybowska, A., and Valsami-Jones, E. (2008). Arsenic pollution sources. Rev. Envion. Contam. Toxicol., 197, 1760. http://dx.doi.org/10.1007/978-0-387-792 84-2_2

Gu, S., Cheng, X., Shen, Z., and Zhang, Q. (2007). Watershed chara- 
cteristics of the upper reaches of the Hanjiang River basin. Resour. Environ. Yangtze Basin, 16(Z2), 38-44.

Hirst, H., Jüttner, I., and Ormerod, S. (2002). Comparing the response of diatoms and macroinvertebrates to metals in upland streams of Wales and Cornwall. Freshw. Biol., 47, 1652-1665. http://dx. doi.org/10.1046/j.1365-2427.2002.00904.x

Hochberg, Y., and Tamhane, A.C. (1987). Mutiple Comparis on Procedures, New York: Wiley. http://dx.doi.org/10.1002/978047031 6672

Kawara, O., Yura, E., Fujii, S., and Matsumoto, T. (1998). A study on the role of hydraulic retention time in eutrophication of the Asahi River Dam reservoir. Water Sci. Technol., 37(2), 245-252. http://dx. doi.org/10.1016/S0273-1223(98)00030-4

Kelly, M.G., and Whitton, B.A. (1995). The trophic diatom index: a new index for monitoring eutrophication in rivers. J. Appl. Phycol., 7(4), 433-444. http://dx.doi.org/10.1007/BF00003802

Kruskal, W.H., and Wallis, W.A. (1952). Use of ranks in one-criterion variance analysis. J. Am. Stat. Assoc., 47(260), 583-621. http://dx.doi.org/10.1080/01621459.1952.10483441

Lenat, D.R., and Crawford, J.K. (1994). Effects of land use on water quality and aquatic biota of three North Carolina Piedmont streams. Hydrobiologia, 294(3), 185-199. http://dx.doi.org/10.1007/BF000 21291

Levene, H. (1960). Robust tests for equality of variances. In I. Olkin (Ed.) Contributions to Probability and Statistics: Essays in Honor of Harold Hotelling (pp. 278-292), Stanford, CA: Stanford University Press.

Li, S., Xu, Z., Cheng, X., and Zhang, Q. (2008a). Dissolved trace elements and heavy metals in the Danjiangkou Reservoir, China. Environ. Geol., 55(5), 977-983. http://dx.doi.org/10.1007/s00254007-1047-5

Li, S., Gu, S., Liu, W., Han, H., and Zhang, Q. (2008b). Water quality in relation to the land use and land cover in the Upper Han River basin, China. Catena, 75(2), 216-222. http://dx.doi.org/10.1016/j. catena.2008.06.005

Li, S., Cheng, X., Xu, Z., Han, H., and Zhang, Q. (2009a). Spa- tial and temporal patterns of the water quality in the Danjiangkou Reservoir, China. Hydrol. Sci. J., 54(1), 124-134. http://dx.doi.org/ 10.1623/hysj.54.1.124

Li, L., Shi, Z., Yin, W., Zhu, D., Ng, S., Cai, C., and Lei, A. (2009b). A fuzzy analytic hierarchy process (FAHP) approach to eco-environmental vulnerability assessment for the Danjiangkou reservoir area, China. Ecol. Model., 220(23), 3439-3447. http://dx.doi.org/ 10.1016/j.ecolmodel.2009.09.005

Lockeretz, W., Shearer, G., and Kohl, D. (1981). Organic farming in the corn belt. Science, 211(6), 540-547. http://dx.doi.org/10.1126/ science.211.4482.540

Mikhailov, L., and Tsvetinov, P. (2004). Evaluation of services using a fuzzy analytic hierarchy process. Appl. Soft Comput., 5(1), 23-33. http://dx.doi.org/10.1016/j.asoc.2004.04.001

Ministry of Envrionmental Protection of the People's Republic of China (2002). Environmental Quality Standards for Water Quality, GB3838-2002, Beijing.

Morán, J., Granada, E., Míguez, J., and Porteiro, J. (2006). Use of grey relational analysis to assess and optimize small bio- mass boilers. Fuel Process. Technol., 87(2), 123-127. http://dx.doi.org/ 10.1016/j.fuproc.2005.08.008

Müller, B., Berg, M., Yao, Z., Zhang, X., Wang, D., and Pfluger, A. (2008). How polluted is the Yangtze river? Water quality downstream from the Three Gorges Dam. Sci. Total Environ., 402(2-3), 232-247. http://dx.doi.org/10.1016/j.scitotenv.2008. 04.049
National Soil Survey Office (1992). Soil Survey Technique in China, Agricultural Press, Beijing, pp. 42-54.

Schmitt, A. (2004). The Influence of Nutrients on Aquatic Primary Production and Food Webs in Subtropical Streams of South East Queensland, Australia, Ph.D. Dissertation, Environmental Sciences, Griffith University, Australia.

Smith, V.H. (2003). Eutrophication of freshwater and coastal marine ecosystems a global problem. Environ. Sci. Pollut. Res. Int., 10(2), 126-139. http://dx.doi.org/10.1065/espr2002.12.142

Søndergaard, J., Asmund, G., Johansen, P., and Elberling, B. (2010). $\mathrm{Pb}$ isotopes as tracers of mining-related $\mathrm{Pb}$ in lichens, seaweed and mussels near a former $\mathrm{Pb}-\mathrm{Zn}$ mine in West Greenland. Environ. Pollut., 158(5), 1319-1326. http://dx.doi.org/10.1016/j.envpol.20 10.01.006

Stoermer, E.F., and Smol, J.P. (eds). (1999). The Diatoms: Applications for the Environmental and Earth Sciences, Cambridge University Press, Cambridge.

Stevenson, R.J., Bothwell, M.L., and Lowe, R.L. (1996). Algal Ecology: Freshwater Benthic Ecosystems, Academic Press.

Soares, M.C.S., Marinho, M.M., Huszar, V.L.M., Branco, C.W.C., and Azevedo, S.M.F.O. (2008). The effects of water retention time and watershed features on the limnology of two tropical reservoirs in Brazil. Lakes Reserv.: Res. Manage., 13(4), 257-269. http://dx. doi.org/10.1111/j.1440-1770.2008.00379.x

Tan, X., Xia, X., Cheng, X., and Zhang, Q.(2011). Temporal and spatial pattern of phytoplankton community and its biodiversity indices in the Danjiangkou Reservoir. Environ. Sci., 32 (10), 59-60.

U.S. Environmental Protection Agency (USEPA) (2012). Edition of the Drinking Water Standards and Health Advisories, Washington, DC.

Vörösmarty, C.J., McIntyre, P.B., Gessner, M.O., Dudgeon, D., Prusevich, A., Green, P., et al. (2010). Global threats to human water security and river biodiversity. Nature, 467, 555-561. http://dx. doi.org/10.1038/nature09440

Webster, A., Bartley, R., Armour, J., Brodie, J., and Thorbrun, P. (2012). Reducing dissolved inorganic nitrogen in surface runoff water from sugarcane production systems. Mar. Pollut. Bull., 65 (4-9), 128-135. http://dx.doi.org/10.1016/j.marpolbul.2012.02. 023

Wei, G., Yang, Z., Cui, B., Li, B., Chen, H., Bai, J., et al. (2009). Impact of dam construction on water quality and water selfpurification capacity of the Lancang River, China. Water Res. Manage., 23(9), 1763-1780. http://dx.doi.org/10.1007/s11269-0089351-8

WHO. (2011). Guidelines for Drinking-Water Quality, 4th ed, World Health Organization.

Xia, J. (1995). Grey associative analysis method used for water quality assessment in a region. Hydrol., 2, 4-10.

Zhang, Q. (2009). The South-to-North Water Transfer Project of China, an overview of its environmental implications. J. Am. Water Resour. Assoc., 45(5), 1238-1247. http://dx.doi.org/10.1111/j.17521688.2009.00357.x

Zhang, Q., Xu, Z., Shen, Z., Li, S., and Wang, S. (2009). The Han River watershed management initiative for the South-to-North Water Transfer Project (Middle Route) of China. Environ. Monit. Assess.,148(1-4), 369-377. http://dx.doi.org/10.1007/s10661-008$0167-z$

Zhu, Z., and Chen, D. (2002). Nitrogen fertilizer use in China-contributions to food production, impacts on the environment and best management strategies. Nutr. Cycling Agroecosyst., 63(2-3), 117127. http://dx.doi.org/10.1023/A:1021107026067 